\title{
Factors Influencing Purchase Intention on Private Label Products*
}

\author{
Nina MAHARANI ${ }^{1}$, Arief HELMI ${ }^{2}$, Asep MULYANA ${ }^{3}$, Meydia HASAN ${ }^{4}$ \\ Received: August 01, 2020 Revised: October 05, 2020 Accepted: October 15, 2020
}

\begin{abstract}
This study aims to develop propositions about the factors that influence the purchase intention of private label products. These factors are: in-store promotion, visual merchandising, store image, and customer value. This study elaborates on some of the results of previous studies that have examined the factors that influence purchase intention of private label products that have been published on Google Scholar and indexed by Scopus between 1991- 2020, to develop a proposition. This paper fills a lack of Studies which discuss purchase intention from a consumer behavior perspective. From the perspective of consumer behavior, purchase intention is influenced by three factors, namely: intrinsic factors including: consumer value, extrinsic factors including: in-store promotions, visual merchandising and store image, and consumer factors. This paper defines purchase intention as the effort and strong urge to buy a particular product in the future, the possibility of considering buying the product, the decision to rebuy the product and the desire to recommend the product. The main findings of this research are several propositions, namely: in-store promotion, visual merchandising and store image directly affect customer value and purchase intention. The following propositions are: In-store promotion, visual merchandising and store image influence purchase intention mediated by customer value.
\end{abstract}

Keywords: Customer Value, In-Store Promotion, Private Label Product, Purchase Intentions, Visual Merchandising

JEL Classification Code: L81, L84, M31

\section{Introduction}

One strategy used to build a store's competitive advantage is by creating a robust retail brand image and providing

\section{*Acknowledgements:}

We would like to state our beholden for the financial support of the Doctoral Dissertation Research Grant Program from the Ministry of Research, Technology and Higher Education. We are very obliged for the help, advice, and input from the editors and reviewers of this article.

${ }^{1}$ First Author and Corresponding Author. Lecturer, Management Department, Faculty of Economics and Business, Universitas Islam Bandung, Indonesia [Postal Address: Tamansari 1, Bandung City, West Java Province, 40116, Indonesia]

Email: nina.maharani68@gmail.com

${ }^{2}$ Lecturer, Management Department, Faculty of Economics and

Business, Universitas Padjadjaran, Indonesia.

Email: arief.helmi@unpad.ac.id

${ }^{3}$ Lecturer, Management Department, Faculty of Economics and

Business, Universitas Padjadjaran, Indonesia.

Email: asep.mulyana@unpad.ac.id

${ }^{4}$ Lecturer, Management Department, Faculty of Economics and

Business, Universitas Padjadjaran, Indonesia.

Email: meydia.hasan@unpad.ac.id

(c) Copyright: The Author(s)

This is an Open Access article distributed under the terms of the Creative Commons Attribution Non-Commercial License (https://creativecommons.org/licenses/by-nc/4.0/) which permits unrestricted non-commercial use, distribution, and reproduction in any medium, provided the original work is properly cited. merchandise with a private label/store brand (Levy et al., 2014). Private label/store brand is an item that is only owned or traded by individual retailers (Sprott \& Shimp, 2004). Private labels can be used to build competitive advantage in stores (Levy et al. 2014) to increase profit, store traffic, and increase the power of negotiation with manufacturers (Batra \& Sinha, 2000) and build store loyalty (Sprott \& Shimp, 2004: Batra \& Sinha, 2000).

Sethuraman and Gielens (2014) state that sales of store brands / private labels around the world have grown over the past two decades. In 2009 the average market share of private label products globally was only $14.9 \%$, but in 2013 the average market share of private label products globally increased to $16.5 \%$. However, sales of private label products in Asian countries, including Indonesia, only reached below $10 \%$. It is due to the retailers' lack of investment in marketing private label products as well as the intense loyalty of consumers to national brands/ manufacturing brands. (Nielsen, 2014). In Indonesia, the average sales figure of own-label products compared to nationally branded products is $2: 10$, this proves that the consumers are less interested in buying private label products, so it takes effort to build purchase intentions for private label products (Besra, Kartini, \& Hasan, 2015).

Herstein et al. (2017) argue that to increase sales of private label products, retailers should use promotions. 
However, in practice, product promotions of private labels are not as extensive as promotions carried out for nationally branded products. Grewal et al. (1998) and Sprott \& Shimp (2004) add to encourage purchases and improve the perceived quality of private labels so that retailers can use instore promotions. Previous research on in-store promotions influenced purchase intentions of private label products (Ye \& Zhang, 2014; Abril \& Canovas, 2016) in-store promotions affect shopping preferences of private label products (Chen, 2009) and build brand equity (Buil et al, 2013)

Another factor which influence purchase intention is visual merchandising. In future, visual appearance is one of the factors that can make our products stand out from competitors on the shelf or online (Grewal et al., 2017), whereas Kahn (2016) highlights the importance of various visual components, increasing consumer attention to encourage buying intentions. Previous research has proved that visual merchandising could encourage consumer buying intentions (Gajanayake et al., 2011; Ha \& Lennon, 2010; Jain et al., 2014; Kerfoot et al., 2003; Kouchekian \& Gharibpoor, 2012; Mary \& Naud, 2015; Law et al., 2012).

Store image is another factor that influenced buying intentions as the opinion of (Bao et al., 2011; Wu et al., 2011; Diallo, 2012; Diallo et al 2015; Besra et al., 2015; Mathur \& Gangwani, 2016; Konuk, 2018) Whereas Liljander et al. (2009) argued that store image influences purchase intention indirectly by reducing risk perception and increasing the quality of store-brand perception.

Customer value is one of the factors driving the purchase intention of a product and private label product (Dodds et al., 1991; Sweeney \& Soutar, 2001; Liljander et al., 2009; Beneke et al., 2013; Rintamäki \& Kirves, 2016; Mohseni et al., 2016; Toufani et al., 2017; Konuk, 2018: and Nikhashemi et al., 2016). Customer values are obtained by evaluating what customers feel as the benefit of owning/ consuming goods (Eggert et al., 2018).

What differs in this research from previous studies is that this study combines variables of previous studies. This study also utilizes customer value as an intervening variable. We will conduct this research at stores which applies the principle of self-service market. Mini markets, supermarkets and hypermarkets sell daily necessities with the principle of self-service.

\section{Literature Review}

\subsection{In-Store Promotion}

Fam et al. (2011) emphasized in-store promotions in the form of individual sales, in-store display, and price reductions. Different opinions expressed by Berman et al, (2018) in-store promotions can be in the form of point of purchase, contests, sweepstakes, coupons, prizes, samples, special events. Yang \& Lee (2016) added promotions in the store in the form of coupons, sweepstakes, free samples, premiums, store atmosphere, interactions with salespeople, as well as attractive packaging. Chen (2009) added that instore promotions must provide benefits, attractiveness, and value to consumers.

\subsection{Visual Merchandising}

Visual merchandising is presenting the most visually appealing products due to the combination of art and science (Ebster \& Garaus, 2015). Mehta \& Chugan (2013) argued retailers can use the art of displaying merchandise in a wonderful manner, thus stimulating consumer purchasing. A broader definition stated by Chandon et al. (2009) says that visual merchandising is a technique that marketers use visually to increase the attractiveness of their outlets by creating a beautiful atmosphere, proper rack arrangement, attractive window display, cleanliness and many other aspects. It triggers impulse purchases among consumers.

\subsection{Store Image}

Chowdhury et al. (1998) and Orth \& Green (2009) expressed a different opinion, they state that the store image is a picture of the store, it is inherent in the mind of the buyer based on core elements such as atmosphere, comfort, price/value, product selection, quality products, and services. According to Diallo (2012), consumers use different elements when evaluating a store. Therefore, the store's image is a multidimensional concept. It includes various aspects of a store, namely: layout, merchandise, and services. Bao et al. (2011) declared that shop image formed from the combination of retail attributes such as store service, shopping environment, product diversity, and quality of merchandise.

\subsection{Customers value of Private Label Products}

Customer value is the consumer's judgment about the benefits of the product based on perceptions of the sacrificed and the received (Zeithaml, 1988). Gallarza \& Gil (2008) said that customer value is the value that arises when consumers own and consume the goods /services they buy. Eggert et al. (2018) confirmed the value in the use of expressing utility of particular objects, while the value in exchange expresses the power to buy other goods owned by the object.

We could classify customer value (Sweeney \& Soutar, 2001) in four dimensions, namely: (1) emotional value is a feeling or affective statement arising after using the product (2) social value is the benefit arising from the ability of the 
product to improve the social concept of self, ( 3) functional value (price/value for money) that is the benefits generated from the product compared to the costs incurred, and (4) functional value (performance/quality) is the expected performance of a product. Walsh \& Mitchell (2010) and Rintamäki \& Kirves (2016) stated four dimensions of customer value commonly used in research on private label products, fashions online and offline, and also electronic online and offline, namely: economic value, functional value, emotional value and social value.

\subsection{Purchase Intention on Private Label Products}

Bilal \& Ali (2013) revealed that there are three factors that influence consumer purchase intentions, namely intrinsic factors including: perceived value, extrinsic factors include: store image, visual merchandising and in-store promotion, while consumer factors include: attitude and trust. Research on attitudes can influence purchase intention has been carried out by Nguyen et al. (2020) who argue that green product purchase intention is positively influenced by the attitude of buying green products and altruism towards the product. Phuong \& Dat (2017) added that consumer purchase intentions are higher if consumer attitudes are more positive towards functional food products.

The likelihood of someone doing certain behaviors reflects intention (Ajzen, 1991). Buying habits reflect behavior planned by potential customers and the likelihood that we will translate the behavior into buying behavior (Engel et al, 1990; Schiffman and Wisenbilt, 2015). Furthermore, Dodds et al. (1991) and Schiffman and Wisenbilt (2015) add that an increase in purchase intention means a possibility of increased purchases. When consumers have positive purchase intentions in the form of commitment to the brand, it encourages consumers to make actual purchases.

Wu et al. (2011) and Shao et al. (2004) argue that buying intention shows the likelihood that consumers will plan or attempt to buy certain products or services in the future, referring to the possibility of consumers to consider buying, or the consumer's decision to repurchase the product. (Shao et al. 2004). Hoang et al. (2020) argued that on the purchase of organic milk products, purchase intention occurs when consumers are aware of the brand, this brand awareness is strengthened or weakened by corporate social responsibility carried out by the company.

\section{Propositions}

This study offers a conceptual framework of factors that influence purchase intentions that are mediated by customer value. The following section explains the relationship between each variable in explaining the purchase intention of private label products.

\subsection{The Impact of In-Store Promotion to Customer Value}

Moliner et al. (2007) and Yoo et al. (2000) show that product, promotion, price, and distribution significantly influence customer value. Chen (2009) argues that promotion of products with private label that are attractive, useful and of good value can encourage consumer shopping preferences. In-store promotions in the form of discounts, premiums are usually used by retailers to increase store traffic, encourage purchase intentions depending on the benefits and perceived value of customers (Grewal et al., 1998; Gauri et al, 2017; Chandon et al., 2009). Yang \& Lee (2016) added that when in-store promotions are attractive, consumers with purchase intentions will react more to retailers' in-store promotions. Iranmanesh (2017) says that price promotions and volume discounts affect purchase intentions. Luo \& Lee (2018) argued discount after purchase either in the form of nominal value or discount percentage can affect consumer desire to repurchase to the company.

\section{Proposition 1: In-store promotions affects customer value}

\subsection{The Impact of Visual Merchandising to Customer Value}

Levy et al. (2014) stated that one way to add value to motivate consumers to shop impulse is to use visual merchandising. Ebster \& Garaus (2015) argues that shopping at stores will meet the following values: efficiency, aesthetics, exploration, and social interaction caused by displaying goods, music, lightings, and if the store layout is a beautiful one. At the same time, the findings of Beneke \& Carter (2015) are that visual merchandising through customer value creates an indirect effect on store brand loyalty. Toufani et al. (2017) state that aesthetics (colour, design, product shape) affect the emotional value and functional value of the stores.

Proposition 2: Visual merchandising affects customer value

\subsection{The Impact of Store Image to Customer Value}

Ryu et al. (2008) and Ryu et al. (2012) argue that the store/ restaurant image directly and significantly influences the customer value. Grewal et al. (1998) reveal the relationship between store image and customer value, consumers will feel the added value felt when buying products in stores that have a positive image. Whereas Beneke et al. (2013) reveals that store image both directly and indirectly influences brand loyalty which is mediated by customer value. Loyalty to store brands arises when the stores' image shapes customer 
value. In contrast, Konuk (2018) believes that the store's image influences customer value through perceived quality. Chang \& Tseng (2013) and Tu \& Chih (2013) stated that store image influences perceived value and utilitarian value.

\section{Proposition 3: Store image affects customer value}

\subsection{The Impact of In-Store Promotion to Purchase Intention}

Grewal et al. (1998) argue that discounted prices are often used by retailers to increase in-store traffic and encourage purchases. Furthermore, Gauri et al. (2017) stated that discounted prices would increase store traffic and store sales. Meanwhile, Palazon \& Ballester (2009) argue that in-store promotions in the form of premiums and discounted prices can encourage purchase intentions depending on the perceived value of consumers to these two promotional tools. Palazon's opinion is reinforced by Yang \& Lee (2016), which states that if in-store promotions are attractive, consumers with purchase intentions will react more to in-store promotions by retailers. Whereas Ye \& Zhang (2014) argued that sales promotions and price promotion activities influence buying intentions.

Proposition 4: In-store promotions affect customer intentions

\subsection{The Impact of Visual Merchandising to Purchase Intention}

Jain et al. (2014) argue storefront that is part of visual merchandising creates pleasant feelings for consumers which leads to consumer buying intentions. Opinions of Gajanayake et al (2011) color, appearance of the product, cleanliness, lighting, and music affect consumer purchase intentions. A different opinion raised by Park et al. (2014). They stated that a positive attitude or liking visual merchandising changed to a favorable brand attitude directly that was positively related to purchase intention. According to $\mathrm{Wu}$ et al. (2014), store layout creates emotional arousal influences buying intentions. Kerfoot et al. (2003) added that merchandise color, presentation style, the distance between shelves, equipment as well as the quality of materials and lighting affect product purchase intentions.

Proposition 5: Visual merchandising affects purchase intentions

\subsection{The Impact of Store Image to Purchase Intention}

Grewal et al. (1998) found a relationship between selfservice image directly to product purchase intentions, so it is essential for companies to improve their image. The same opinion was stated by Champion et al. (2010) which states that the store's image influences the willingness of consumers to buy products, where consumers judge that supermarkets that have an unfavorable image carry low-quality products as well. Whereas Liljander et al. (2009) argued that store image influences purchase intention indirectly by reducing risk perception and increasing the quality of store-brand perception.

Store image significantly influenced the purchase intention of products private label (Diallo, 2012; Bao et al., 2011; and $\mathrm{Wu}$ et al., 2011; Diallo et al., 2015). Hu (2011) added that merchandise management, harmony, and comfortable store atmosphere significantly influences shopping intentions and shopping frequency. Hu's statement was supported by Konuk (2018), who stated that increased buying intentions were influenced by customer value, trust in private organic labels, product quality, and positive store image.

Proposition 6: The store's image affects Purchase intentions

\subsection{The Impact of Customer Value to Purchase Intention}

Customer value is a vital determinant in repurchase intentions using online channels (Chang \& Wang, 2011). A similar opinion was expressed by (Dodds et al., 1991; Grewal et al., 1998; Beneke et al., 2013) the perceived value of the customer directly influences the desire to buy. The findings of Kakkos et al. (2015) that risk perception, value for money, social value are the main driving factors of consumers' purchase intentions for products' private labels.

Liljander et al. (2009) and Konuk (2018) emphasized that the main factor driving the purchase intention of products private labels is customer value. Mohseni et al. (2016) added that personal value, shopping experience, and perceived risk affects purchase intentions using the website, while Lien et al. (2015) stated purchase intentions were directly affected by three essential factors: brand image, price, and perceived value.

\section{Proposition 7: Customer value affects purchase intention}

Based on the literature discussed above, the variables proposed in this study are determining factors that influence purchase intention of private label products, including instore promotions, visual merchandising, store image, and customer value. Figure 1 shows the relationship between each proposed construct. 


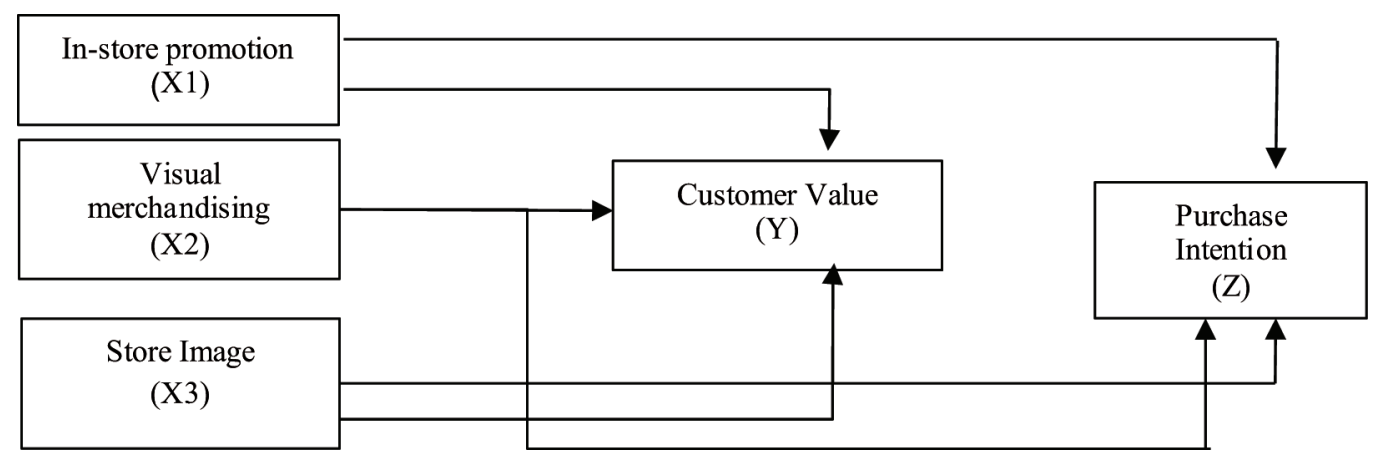

Figure 1: Relationship between each proposed Variable

\section{Conclusion}

We purpose this study to develop propositions about the factors that influence the purchase intention of private label products. The findings of this research are several propositions, namely: in-store promotions, visual merchandising and store image directly affect customer value and purchase intention. The following propositions are: In-store promotion, visual merchandising and store image influence purchase intention mediated by customer value. However, based on previous research, it has been found that there are gaps in the literature discussing the factors that influence the purchase intention of private label products. This research offers a proposition to explain and fill the gap in research.

\section{References}

Abril, C., \& Rodriguez-Cánovas, B. (2016). Marketing mix effects on private labels brand equity. European Journal of Management and Business Economics, 25(2016), 168-175.

Ajzen, I. (1991). The theory of planned behaviour. Organisational Behaviour and Human Decision Processes, 50(2), 179-211.

Bao, Y., Bao, Y., \& Sheng, S. (2011). Motivating purchase of private brands: Effects of store image, product signatures, and quality variation. Journal of Business Research, 64(2), 220-226.

Batra, R., \& Sinha, I. (2000). Consumer-level factors moderating the success of private label brands. Journal of Retailing, 76(2), $175-191$.

Bilal, M., \& Ali, T. (2013). Factors Influencing Consumers Purchase Intentions towards Private Brands. Journal of Independent Studies and Research-Management, Social Sciences, and Economics, 11(2), 17-28.

Beneke, J., \& Carter, S. (2015). The development of a consumer value proposition of private label brands and the application thereof in a South African retail context. Journal of Retailing and Consumer Services, 25, 22-35.

Beneke, J., Flynn, R., Greig, T., \& Mukaiwa, M. (2013). The influence of perceived product quality, relative price, and risk on customer value and willingness to buy: A study of private-label merchandise. Journal of Product \& Brand Management, 22(3), 218-228.

Berman, B., Evans, JR, \& Chatterjee, P. (2018). Retail Management A Strategic Approach (13 ${ }^{\text {th }}$ ed.). London, UK: Pearson Education Limited.

Besra, E., Kartini, D., \& Hasan, M. (2015). The role of retail image and customer trust on purchase intention of private label products. International Journal of Scientific \& Technology Research, 4(5), 215-218.

Buil, I., De Chernatony, L., \& Martínez, E. (2013). Examining the role of advertising and sales promotions in brand equity creation. Journal of Business Research, 66(1), 115-122.

Chang, E. C., \& Tseng, Y. F. (2013). Research note: E-store image, perceived value, and perceived risk. Journal of Business Research, 66(7), 864-870.

Chang, H. H., \& Wang, H. W. (2011). The moderating effect of customer perceived value on online shopping behavior. Online Information Review, 35(3), 333-359.

Chandon, P., Hutchinson, J. W., Bradlow, E. T., \& Young, S. H. (2009). Does in-store marketing work? Effects of the number and position of shelf facings on brand attention and evaluation at the point of purchase. Journal of Marketing, 73(6), 1-17.

Champion, J. C., Hunt, J. B., \& Hunt, T. G. (2010). The Effect of Retail Store Image on Student Perceptions of Merchandise Quality and Willingness to Buy. American Journal of Business Research, 3(1), 17-32.

Chowdhury, J., Reardon, J., \& Srivastava, R. (1998). Alternative modes of measuring store image: An empirical assessment of structured versus unstructured measures. Journal of Marketing Theory and Practice, 6(2), 72-86.

Chen, C. L. (2009). Strategic thinking leading to a private brand strategy that caters for customers' shopping preferences in retail marketing. African Journal of Business Management, 3(11), 741.

Diallo, M. F. (2012). Effects of store image and store brand priceimage on store brand purchase intention: Application to an emerging market. Journal of Retailing and Consumer Services, 19, 360-367.

Diallo, M. F., Burt, S., \& Sparks, L. (2015). The influence of image and consumer factors on store brand choice in the Brazilian 
market: Evidence from two retail chains. European Business Review, 27(5), 495-512.

Dodds, W. B., Monroe, K. B., \& Grewal, D. (1991). Effects of price, brand, and store information on buyers' product evaluations. Journal of Marketing Research, 28(3), 307-319.

Ebster, C., \& Garaus, M. (2015). Store design \& Visual Merchandising: Creating Store Space That Encourages Buying ( $2^{\text {nd }}$ ed.). New York, NY: Business Expert Press.

Eggert, A., Ulaga, W., Frow, P., \& Payne, A. (2018). Conceptualizing and communicating value in business markets: From value in exchange to value in use. Industrial Marketing Management, 69, 80-90.

Engel, J. F., Blackwell, R., \& Miniard, P. (1990). Consumer Behavior (6th ed.). Chicago, IL: The Dryden Press.

Fam, K. S., Merrilees, B., Richard, J. E., Jozsa, L., Li, Y., \& Krisjanous, J. (2011). In-store marketing: A strategic perspective. Asia Pacific Journal of Marketing and Logistics, 23(2), 165-176.

Gallarza, M. G., \& Gil, I. (2008). The concept of value and its dimensions: A tool for analyzing tourism experiences. Tourism Review, 63(3), 4-20.

Gauri, D. K., Ratchford, B., Pancras, J., \& Talukdar, D. (2017). An empirical analysis of the impact of promotional discounts on store performance. Journal of Retailing, 93(3), 283-303.

Gajanayake, R., Gajanayake, S., \& Surangi, H. A. K. N. S. (2011, March). The impact of selected visual merchandising techniques on patronage intentions in supermarkets (study based on Colombo district). In: Proceedings of the Second International Conference on Business and Economic Research (pp. 11301154).

Grewal, D., Krishnan, R., Baker, J., \& Borin, N. (1998). The effect of store name, brand name and price discounts on consumers' evaluations and purchase intentions. Journal of Retailing, 74(3), 331-352.

Grewal, D., Roggeveen, A. L., \& Nordfält, J. (2017). The future of retailing. Journal of Retailing, 93(1), 1-6.

Ha, Y., \& Lennon, S. J. (2010). Online visual merchandising (VMD) cues and consumer pleasure and arousal: Purchasing versus browsing situation. Psychology \& Marketing, 27(2), 141-165.

Hu, H. (2011). Chinese Consumers store Image Formation and Its Impact on Patronage Behavior. Academy of Marketing Studies Journal, 15(2), 83.

Herstein, R., Dori, N., Berger, R., \& Barnes, B. R. (2017). Exploring the gap between policy and practice in private branding strategy management in an emerging market. International Marketing Review, 34(4), 559-578.

Hoang, X. L., Nguyen, T. K. C., Ly, H. M., Luong, T. T., \& Nguyen, T. T. Q. (2020). The moderating role of csr associations on the link between brand awareness and purchase intention. Journal of Asian Finance, Economics and Business, 7(6), 233-240. https://doi.org/10.13106/jafeb.2020.vol7.no6.233
Iranmanesh, M., Jayaraman, K., Zailani, S., \& Ghadiri, S. M. (2017). The effects of consumer perception of volume discount benefits on an intention to purchase grocery products: deal proneness as a moderator. Asia Pacific Journal of Marketing and Logistics, 29(5), 1017-1035.

Jain, V., Takayanagi, M., \& Malthouse, E. C. (2014). Effects of show windows on female consumers' shopping behavior. Journal of Consumer Marketing, 31(5), 380-390.

Kakkos, N., Trivellas, P., \& Sdrolias, L. (2015). Identifying drivers of purchase intention for private label brands. Preliminary evidence from Greek consumers. Procedia-Social and Behavioral Sciences, 175, 522-528.

Kahn, B. E. (2017). Using visual design to improve customer perceptions of online assortments. Journal of Retailing, 93(1), 29-42.

Kerfoot, S., Davies, B., \& Ward, P. (2003). Visual merchandising and the creation of discernible retail brands. International Journal of Retail \& Distribution, 31(3), 143-152.

Konuk, F. A. (2018). The role of store image, perceived quality, trust and perceived value in predicting consumers' purchase intentions towards organic private label food. Journal of Retailing and Consumer Services, 43, 304-310.

Kouchekian, M., \& Gharibpoor, M. (2012). Investigation the relationship between visual merchandising and customer buying decision case study: Isfahan hypermarkets. International Journal of Academic Research in Economics and Management Sciences, 1(2), 2226-3624.

Law, D., Wong, C., \& Yip, J. (2012). How does visual merchandising affect consumer affective response? An intimate apparel experience. European Journal of Marketing, 46(1/2), 112-133.

Luo, X., \& Lee, J. J. (2018). The effect of post-purchase discount format on consumers' perception of loss and willingness to return. Journal of Asian Finance, Economics and Business, 5(4), 101-105. https://doi.org/10.13106/jafeb.2018.vol5. no4.101

Levy, M., Weitz, B. A., \& Grewal, D. (2014). Retailing Management ( $9^{\text {th }}$ ed.). New York, NY: McGraw Hill.

Liljander, V., Polsa, P., \& Van Riel, A. (2009). Modeling consumer responses to an apparel store brand: Store image as a risk reducer. Journal of Retailing and Consumer Services, 16(4), 281-290.

Lien, C. H., Wen, M. J., Huang, L. C., \& Wu, K. L. (2015). Online hotel booking: The effects of brand image, price, trust and value on purchase intentions. Asia Pacific Management Review, 20(4), 210-218.

Mehta, N., \& Chugan, P. K. (2013). The impact of visual merchandising on impulse buying behavior of consumer: A case from Central Mall of Ahmedabad India. Universal Journal of Management, 1(2), 76-82.

Mohseni, S., Jayashree, S., Rezaei, S., Kasim, A., \& Okumus, F. (2016). Attracting tourists to travel companies' websites: The structural relationship between website brand, personal value, 
shopping experience, perceived risk, and purchase intention. Current Issues in Tourism, 21(6), 616-645.

Mary,J.,\&Thibaud,N.(2015).MerchandisingTechniquesinHalmstad Hypermarkets. Thesis in Business and Economics. Halmstad University.

Mathur, M., \& Gangwani, S. (2016) The Effect of Retail Store Image Dimensions on Consumer's Purchase Intention of Private Label Brands. International Journal of Research in Finance and Marketing, 6(11), 89-102.

Moliner, M. A., Sánchez, J., Rodríguez, R. M., \& Callarisa, L. (2007). Relationship quality with a travel agency: The influence of the postpurchase perceived value of a tourism package. Tourism and Hospitality Research, 7(3-4), 194-211.

Nielsen, N. V. (2014). The state of private labels around the world. Retrieved from: http://www. Nielsen. com/be/en/insights/ reports/2014/the-state-of-private-label-around-the-world.html

Nikhashemi, S. R., Tarofder, A. K., Gaur, S. S., \& Haque, A. (2016). The effect of customers' perceived value of retail store on relationship between store attribute and customer brand loyalty: Some insights from Malaysia. Procedia Economics and Finance, 37, 432-438.

Nguyen, T. K. C., Nguyen, D. M., Trinh, V. T., Tran, T. P. D., \& Cao, T. P. (2020). Factors affecting intention to purchase green products in Vietnam. Journal of Asian Finance, Economics and Business, 7(4), 205-211. https://doi.org/10.13106/jafeb.2020. vol7.no4.205

Orth, U. R., \& Green, M. T. (2009). Consumer loyalty to family versus non-family business: The roles of store image, trust, and satisfaction. Journal of Retailing and Consumer Services, 16(4), 248-259.

Palazon, M., \& Delgado-Ballester, E. (2009). Effectiveness of price discounts and premium promotions. Psychology \& Marketing, 26(12), 1108-1129.

Park, H. H., Jeon, J. O., \& Sullivan, P. (2014). How does visual merchandising in fashion retail stores affect consumers' brand attitude and purchase intention? The International Review of Retail, Distribution and Consumer Research, 25(1), 87-104.

Phuong, N. N. D., \& Dat, N. T. (2017). The Effect of Country-ofOrigin on Customer Purchase Intention: A Study of Functional Products in Vietnam. Journal of Asian Finance, Economics and Business, 4(3), 75-83. https://doi.org/10.13106/jafeb.2017. vol4.no3.75

Rintamäki, T., \& Kirves, K. (2016). From perceptions to propositions: Profiling customer value across retail contexts. Journal of Retailing and Consumer Services, 37, 159-167.

Ryu, K., Han, H., \& Kim, T. H. (2008). The relationships among overall quick-casual restaurant image, perceived value, customer satisfaction, and behavioral intentions. International Journal of Hospitality Management, 27(3), 459-469.

Ryu, K., Lee, H. R., \& Kim, W. G. (2012). The influence of the quality of the physical environment, food, and service on restaurant image, customer perceived value, customer satisfaction, and behavioral intentions. International Journal of Contemporary Hospitality Management, 24(2), 200-223. https://doi.org/10.1108/09596111211206141

Sethuraman, R., \& Gielens, K. (2014). Determinants of store brand share. Journal of Retailing, 90(2), 141-153.

Schiffman, L. G., \& Wisenbilt. J. (2015). Consumer Behavior $\left(11^{\text {th }}\right.$ ed.). New York, NY: Pearson Education Limited.

Shao, C. Y., Baker, J. A., \& Wagner, J. (2004). The effects of the appropriateness of service contact personnel dress on customer expectations of service quality and purchase intention: The moderating influences of involvement and gender. Journal of Business Research, 57(10), 1164-1176.

Sprott, D. E., \& Shimp, T. A. (2004). Using product sampling to augment the perceived quality of store brands. Journal of Retailing, 80(4), 305-315.

Sweeney, J. C., \& Soutar, G. N. (2001). Consumer perceived value: The development of a multiple-item scale. Journal of Retailing, 77(2), 203-220.

Tu, Y. T., \& Chih, H. C. (2013). An empirical study of corporate brand image, customer perceived value, and satisfaction on loyalty in the shoe industry. Journal of Economics and Behavioral Studies, 5(7), 469-483.

Toufani, S., Stanton, J. P., \& Chikweche, T. (2017). The importance of aesthetics on customers' intentions to purchase smartphones. Marketing Intelligence \& Planning, 35 (3), 316-338

Walsh, G., \& Mitchell, V. W. (2010). Consumers' intention to buy private label brands revisited. Journal of General Management, 36(1), 3-24.

Wu, P. C., Yeh, G. Y. Y., \& Hsiao, C. R. (2011). The effect of store image and service quality on brand image and purchase intention for private label brands. Australasian Marketing Journal, 19(1), 30-39.

Wu, W. Y., Lee, C. L., Fu, C. S., \& Wang, H. C. (2014). How can online store layout design and atmosphere influence consumer shopping intention on a website? International Journal of Retail \& Distribution Management, 42(1), 4-24.

Ye, L. R., \& Zhang, H. H. (2014). Sales promotion and purchasing intention: Applying the technology acceptance model in consumer-to-consumer marketplaces. International Journal of Business, Humanities, and Technology, 4(3), 1-5.

Yang, D. J., \& Lee, C. W. (2016). In-store promotional mix and the effects on female consumer buying decisions in relation to cosmetic products. International Journal of Management, Economics and Social Sciences, 5(2), 35-56.

Yoo, B., Donthu, N., \& Lee, S. (2000). An examination of selected marketing mix elements and brand equity. Journal of the Academy of Marketing Science, 28(2), 195-211.

Zeithaml, V. A. (1988). Consumer perceptions of price, quality, and value: a means-end model and synthesis of evidence. Journal of Marketing, 52(3), 2-22. 